\title{
EMPIRE AND DEMOCRACY, A CRITICAL READING OF MICHAEL IGNATIEFF
}

Maximiliano E. Korstanje

Universidad de Palermo, Argentina

http://dx.doi.org/10.5209/rev_NOMA.2013.v38.42907

\begin{abstract}
Empires expand their hegemony combined two contrasting forces; one is violence the second is characterized by persuasion. Ideology works in these contexts, as an efficient instrument of self-indoctrination whereby dominated cultures accept the cultural matrix of empire. In this vein, the present essay-review not only questions the employment of human rights in the liberal thought, but also tries to respond to the conceptual problems of liberalism to understand terrorism. Based on two seminal texts written by the liberal Michael Ignatieff, we formulate the thesis that liberalism supports the war against terror because of its doctrine of self-determination.
\end{abstract}

Keywords.- Ignatieff, democracy, war-mongers, empires

\section{Introduction}

The present essay review explores the conceptual obstacles, problems and contributions of Michael Ignatieff respecting to the theory of Human Rights. From 9/11 onwards, many analysts saw the turning point of a new facet, whereby fear played a crucial role. The precautionary principle as it has been coined in Europe led state to act under the logic of pre-emption, declaring the preventive war against other states. The preventive attack resulted from the logic of pre-emption is based on the future. This exhibits the sign of new times, when future rules over present (Baudrillard, 2006). One of the most problems the liberal thought faced in this context was the unilateral justification of preventive war in US and Europe. The existent jurisprudence stipulates that states do not declare the war to other state excepting if anyone has substantial evidence of a next blow. The boundaries between substantial evidence and justifications seem to be slim. Precisely, liberalism was a thought born to respect plurality and multiculturalism. How can a liberal pave the ways to legitimate the American war on terror?. To respond this question, we have painstankely examined the work of Michael Ignatieff and his development along with the connection between the doctrine of self-determination and human rights. In so doing, some conceptual misunderstandings not only facilitate the acceptance of preventive against terrorism but also dispense a criticism on the concept of human right itself. Born in 1947 and well known as Canadian historian, Ignatieff was educated in the core of Anglo Canadian thought. In his career he was lecturer at prestigious universities as Cambridge, Harvard and Oxford. Elected as chief of liberal party in Canada from 2008 / 2011, Ignatieff 
consolidated a theory on human rights and jurisprudence to understand the collateral effect of terrorism for democracy.

A. Schopenhauer confirmed that events are classified because we have a conceptual frame to sort the meanings. Any situation can be less or more controlled, but what is important is our feeling of being in charge. The idea of freedom or free choice remains in absurd, an illusion brought by Anglo-Saxon cosmology. The word is given to human mind by dint of experience. When we admit our freedom, we accept our limitation to decide between two doors, two courses of actions. At time we opt for A, B option is closed. Therefore, our decision is not liberated to all option; rather it is limited to our finitude (Schopenhauer, 2007). In a moment of history, the ideology of freedom was imposed to feudal form of life.

\section{Preliminary Discussion}

In the book Human Rights, Ignatieff clarifies that United States has promoted the respect of human assistance but at the same time refused the application of any resolution when its doctrine of self-determination is at stake. Human Rights are not good or bad, they are necessary, Ignatieff adds. After WWII, the world witnessed the emergence of two contrasting view-points. Nazism has propounded that humankind, doted of all benefits and rights. This group juxtaposed to the "untermenschen" whose rights were systemically vulnerated. In view of this, the successive covenants and international agreements signed by western countries were aimed at preventing similar crippling damage produced by Nazism. What is important to discuss here is that human rights recovered the identity of self; in other terms, the egalitarian nature of humanagency (Ignatieff, 2001). Well the problem lies that originally many countries signed to the agreement but in fact did not move any resource to grant the human rights of ethnic minorities. This provoked that many NGO or activists struggled to impose the agenda of Human Rights in the international organism of credit, and commerce to the extent to pose this as a central ideology in American administration. This does not improve the situation of vulnerated minorities because at time the rights of some groups are protected, the other ones are violated.

Nonetheless, US created a state of exception based on its right of selfdetermination in homeland. The intervention of any outsider country in US would be considered a direct attack against the sovereignty of this nation and repelled accordingly. This opens a paradox precisely when US is the country which violates human rights of other minorities. Whilst these human rights found a new constitutional human agency, at the same time invests protection on US as the international police of the world, where human right violation cannot be punished. Quite aside from this, Ignatieff points out human rights are morally based on the need of respect and tolerance, a grounding aspect of what human means.

With the benefits of hindsight, he recognizes that this turn point leads to political narcissism because promotes that the land of democracy should be questioned or falls under the dilemma that US has nothing to learn from others. For that, Europeans and Canadian claim that US violates systematically the Declaration of Human Rights, accepting as fundamental the capital punishment in its soil. 
Rather, the public opinion does not share this view and consider the capital punishment as an expression of the self-determination. Ignatieff argues convincingly that human rights rests on a paradox. Those states which should protect for their vulnerable minorities, take advantage of their privileged situation to eradicate them. This is the reason why we cannot situate the principle of self-determination in the discussion of human right interpretation. First and most important, minorities wander through the world lacking of a state to reach protection. Secondly, by strengthening the resource of states is a way to improve the instrument to vulnerated the rights of minorities. Whatever the case may be, democracy and human rights has limits in their applications. Activists should understand that communities have right to live as they want. Any right is not only political but also remains enrooted in a previous legal framework that precedes how this right is applied. The idealization of human rights is dangerous because it leads US to make an imperial interpretation of the needs of intervention. Given this, one might understand the problem as a dichotomy between two sides, two interpretations: human rights as politics, and human rights as idolatry. The former refers to the application of rights to protect the vulnerability of people while the others is a sacred belief that aims to think the concept of human rights resolve all our disputes as civilization.

The cold-war reserved two super powers, each one with the right to intervene in their peripheries but once the soviet bloc collapsed, US transformed in an all encompassing power which unless otherwise resolved may become in a dictatorship. Human rights as idolatry are the pretexts for army-led invasions to autonomous countries. At the time, US leans to a more political application of human right, less possibility for democracy to run out. Human rights should be discussed in the table of international foreign affairs to agree multilateral consensus. This seems to be exactly what activists and human right proponents do not understand. They are exacerbated the human rights to be applied in all spheres of human beings. This not only is dangerous but also keeps the situation out of control. If we assume that human right's doctrine may resolve international disputes is as illogic as precluding that anti-abort struggle. For example, detractors and proponents of abort agree that nobody has the right to take the life of someone, but there are conceptual limitations at time of settling when a fetus reaches the status of human being. Ignatieff understands clearly the conflict of interpretations given in disputes of this calibre. He adds, this happens because conflict and disputes are part of politics. For that, human rights should not been contemplated beyond the boundaries of conflict and politics. Prohibiting the abort, we are violating the basic human rights as if we promote it. The solution rests on the deliberative democracy, which facilitates the condition of debate.

Last but not least, Ignatieff acknowledges that his criticism is not directed against human rights but to the idolatry given by activists. They like to create a universal matrix that transcends all types of cultural interpretation, no matter than the moral and cultural values of each folk. In a democracy, rules must be protected but very well may be altered if the conditions of stability are broken. To avoid democracy is not trapped in the same it promotes, it is necessary to recur to the construction of a constitutional order, a main text that legislates on almost all problems of community. Otherwise, we witness how democracy set the pace to the dictatorship of majority. In the democratic life, rebels and 
isolationist attempts of independence can be negotiated in the deliberative logic, sometimes giving representation in the parliament, others accepting some of their demands. In any case, democratic nations should accept claims imposed by terror, violence or extortion. With the end of grating the freedom of isolationist groups, the negotiation should be situated under the lens of scrutiny of other democratic states. Most certainly, the discrepancy between selfdetermination and human rights are resolved in view of three key factors, a) the deliberative democracy, b) the struggle of all state against terrorism, c) the right of intervention of democratic states to respect the liberties of minorities.

Ignatieff goes on to say overtly that

"So Human rights might best fortified in today's World not by weakening of already overburdened states but by their being strengthened wherever possible. State failure cannot be rectified by human right activism on the part of NGO's. What is required when state fail is altogether more ambitious; regional powers brokering peace accords between factions, peacekeeping forces to ensure that truces stick, multilateral assistance to build national institutions, like tax collection, police forces, courts, and basic welfare services" ( $p$ 35)

Starting from the premise that human rights are granted only under negative liberty, it is important not to loose the sight they only can be thought in the moral individualism. Persons cannot be protected without their authorization. If human rights are applied out of context, we run the risk to face allegations to make a false aporia to legitimate our own interests. What characterized the lack of criticism of the most terrible fascist regimes was not their cruelty, but the fully obedience and devotion the follower showed by their leaders. To prevent that, we must build the individual agency of morality. The theory of human rights recovers the old project of Enlightenment, which envisaged the human being as a particular entity morally divided. Nobody can be forced to obey unmoral orders. As the previous argument given, Ignatieff says that minimalism promotes the belief that the nature of right is not associated to protecting groups, but only to protect the subject that take part. Therefore, the idolatry interpretation of human right has to do with religion and not with politics. Rights are discussed in the field of politics, because what the declaration resolved is our capacity to take a decision about our fate,

"What the declaration does mandate is the right to choose, and specifically the right to leave when choice is denied. The global diffusion of right language would never have occurred had these not been authentically attractive propositions to millions of people, specially women, in theocratic, traditional, or patriarchal societies" (p. 70)

Neither human rights should be seen as good for people, but necessary and just, nor mandatory and universally applied to all cultures. Evocation of these rights is only possible to the petition of victims before a broader state. Nonetheless, this begs an interesting question, what role plays terrorism to undermine the democratic tenets of a Republic?

On his book the Lesser Evil, political ethics in an Age of Terror, Ignatieff recapitulates on the needs to admit that democratic states reduces their warrants in context of disorder and instability. The constitution, the stepping stone of the society has no application in context of emergency. Whenever this temporal condition is continuously expanded to legitimate political interests, the 
democracy is underplayed in favor of the surfacing of dictatorship. Terrorism not only enables these types of conditions but evokes the need to establish the lesser evil for society. The unjust act of war is impossible to prevent, but only in democracy that cruelty can be regulated. The self control of democratic institutions outweighs the abuse of some others in moment of uncertainty. The liberty of people is undermined because the state should predict when the next blow will take form. What seems to be important to take in mind, if this is only temporal or adopted as a tactic to introduce policies that otherwise would be rejected.

Ignatieff enumerates three forms state intervenes in crisis:

NATIONAL refers to the suspension of constitutional liberties to further notice in all territory.

TERRITORIAL signals to some provinces of colonies where individual rights are not observed.

SELECTIVE is based on the suspension of liberties for some ethnic minorities while the state of right is valid in the rest of country.

What Ignatieff discusses is that before the next terrorist attack, state very well recur to violation of some human rights because expand the torture as a mechanism of struggle. The derived consequences, rather, may be disastrous if these practices persist in a long term. The lesser evil doctrine attempts to galvanize the discussion between realist and moral purists respecting to torture. The goal of democracy is to grant the logic of deliberation and participation as practice enrooted in the political fields. The degree of violence exerted on the bodies in democracy should be limited to affect temporarily only few people. Democracy decides on two evils, the greater and the lesser one. To here, we have synthesized as objective as possible the development of Ignatieff on the human rights, terrorism and democracy.

\section{Criticism to Ignatieff's development}

By keeping with democracy, Robert Castel (2006) explains that industrial revolution has liberalized the social bonds, originally coined in Middle Age, in order to be canalized to mass-consumption. The introduction of liberty as a universal concept was conducive to industrialism and later to the consolidation of capitalism. At some extent, this has triggered an asymmetry of power between citizens and officials. This gap is fulfilled by international business corporations with the end of protecting the interest of elite. Castel describes how the success of capitalism depended on the adoption of new paradigms that modify the relationship of human beings with their kinship, soil, and labor. Rationale, on one hand, closed the uncertainty opened by the liberty pushing workers to decide on their best alternative of work. Moved exclusively by their psychological needs, work-force migrated to sell their work to new owners. Without the concept of freedom, this change would never have been possible.

Whenever, C. Castoriadis claimed that democracy was dead forever after the Peloponnesus war, he was right. Castoriadis recognizes the divergence between classic and modern democracy. Greeks, far war of defying the authority of their king, accepted democracy only as a resource to derogate a 
law if it was unjust. Without Christendom as moral regulator, Greeks believed on the law of stronger. The world was not created to be administered by human beings; they should demonstrate their superiority to rule over it. The agriculture, slavery and war were the key factors of ancient Greece. The modern conception of liberty is given by the liberalization of work-forces. The anglo-Saxon empires (United Kingdom and United States) not only tergiversated the meaning of democracy but impeded the lay-people to take active participation in the sanction of laws. The old liberty of Greeks set the pace to a new one, corporative and manipulated by elite to stimulate the massconsumption. Therefore, we must speak of anglo-democracy as the political expression of republican values as well as the laws which are sanctioned by corporations (Korstanje, 2013).

Not surprisingly, the ancient form of democracy is manipulated into coherent forms of consumptions, where the vulnerability of workers rises. As a result of this, the production of goods is posed to stimulate consumption and protect the system from glitches. The social bonds wane in favor of a homogenous mass without hierarchies, or defined roles, leading people to uncertainty and despair. In this sense, the fear for others not only reinforces the boundaries of the economic system but generate an instrument of indoctrination to preserve the consciousness of capital.

Secondly, human rights as Ignatieff imagined, tend to the dictatorship of the "unique" by two main reasons. The theory of sovereignty alludes to think that a democratic state may exert the violence to intervene other, or being subject to the force of a third state, if necessary (this means when the democracy is on danger). If the self-determination is explained in the roots of the sate, democracy expels rejection to be intervened by a third state. If this is correct, the state of exception of US was not a result of the cultural values but a vicious in the way of thinking the boundaries of constitutional democracy. Further, Ignatieff ignores the harsh criticism of $\mathrm{C}$. Sunstein and R. Dworking on the constitutional interpretations. Dworking has formulated a coherent thesis that explains how judges join in corporations that defend the interests of status quo. Based on the pretext to protect the citizen's liberty, judges take a biased and contextual reading of constitution to encourage some issues while discouraging others. For example, this has been widely documented by Dworking; the supreme court may promote the slavery as well as the over-work if these policies are conducive to the elite.

M. Freeman (2011) follows the same argument considering that human rights are only conceptual construes, which are employed in context of turbulence and uncertainty to decide on certain issues. However, these rights are built on a broader criterion of selection where some values are more important than others. In this vein, human rights only are circulating in public opinion whenever the perceived security of community is on danger. In other situations, they lack of practical applications.

Michael Waltzer (1992) confirmed that any war-fare or direct intervention resulted from the idea to prevent an external blow seems to worsen the situation. The quest of a solution is given by the meeting and negotiation. Although wars may be codified to prevent the attacks against civilians and noncombatant people, effects affect directly or indirectly the civilians because 
attacks destroy the economic infrastructure that they need to survive. To formulate a dichotomy between just or unjust war is functional to the pretext to the interest of those who exert pressure to declare the war.

Third, if we think that human right can be universally applied to all human beings, this suggests that only one state (a super super power) is enough to grant the communal safety. As this argument given, its formulation merits to question to what extent human rights are functional to the dictatorship of "human rights". Besides, minorities had not developed abilities to anticipate the acts of their states. If minorities will be exterminated in a later day, they have no way of asking the protection of other states as Ignatieff insists. Although he knows the danger of preemption, this means the preventive intervention, the design of human rights are drawn to constitute an international police power, amalgamated by various or few stronger states.

J. Albrecth-Meylahn criticizes to Ignatieff that the use of violence is proportional to pervasive counter-effects. Based on the contribution of S. Zizek, any revolution is condemned the same cruel acts previously criticized by them before the coup. This happens because of two primary motives. The first and most important, the physical violence may fluctuate, but if the systemic violence is not extirpated, the material asymmetries that triggered the revolution persist. On this logic, Ignatieff is unable to resolve the paradox situation of torture the most democratic nation of the world, US, today encourages.

Gutmann (2001) tackles off the text of Ignatieff alluding that his problem is the concept of sovereignty. It is based on the need to believe in the negative liberty. Ignatieff's account is troublesome because of the following reasons:

- $\quad$ if we decide to appaling a woman because of infidelity, why US allows the capital-punishment?.

- $\quad$ Sovereignty is the first archetype, which appeal those states at time of violating the human background.

- $\quad$ As formulated by West, human right looks to develop an ethnocentric view of self determination, a chauvinistic expression of nationhood.

Guttmann goes ahead, and says that the quandary in Ignatieff is to believe that the self-defense and self determination are natural values. If states are drawn to grant the well being of their members (the protection of the weak), the human rights confers legitimacy to the law of stronger. Gutmann considers that nationalism is the main problem of human right theory.

The way Ignatieff understands the legal jurisprudence poses serious challenge for liberal thought, and of course this waked up a serious criticism. A Appiah (2001) contemplates that rights are not subject or individual but applied collectively. Rights are not derived from deliberation, as Ignatieff says, but a previous covenant among involved parts. The first of contradiction is to say that rights are enrooted in subjectivism, because it calls to sedition, to the desegregation of colonies or indexed communities of a state. In the same token, D. A Hollinger (2001) establishes Ignatieff formulates a theory to interpelate the periphery, to other cultures in a one-sided gaze. If we apply on individual rights we are appealing to the civil wars. T. Laqueur (2001) coincides with Ignatieff on the importance of human rights for international agenda, but his view is romantic. It is not necessary too much effort to realize the history of 
$X X$ th century is fraught of genocides, ethnic cleansing and civil wars where the human rights were systematically violated. The evolution of sate, if we pay the necessary attention, was given by centuries of struggle and war. Whenever a power disarticulates another state by its intervention, as Elias put it, the chaos emerges. While state has been consolidated by thousand years of violence and war, with thousand of victims, intervention in other political structures should be carefully conducted. This has been a typical error the fear-mongers, as Ignatieff, does not contemplate.

Last but not least, Ignatieff does not understand clearly the roots of terrorism. G. Skoll explains that the function of state is to maintain the hierarchical status quo by exerting power and violence over populations. In times of low conflict, the legitimacy of state rests on the market which confers certain stability. In the context of relative chaos and disorder the state resorts to violence to refashion the threatened order. Similarly, the market mediates among human beings by imposing a state of gratification in lieu of constraints, but the moment the control weakens, fear replaces gratification as motivator to legitimize the ruling order (Skoll, 2007). Terrorism, however, situates as a mirror of western style of life. They are not ill-minded persons who want to destroy our civilization, but a radical experiment of our form of connecting with otherness. Terrorists, let remind to readers, were educated in the best western universities, they earned a degree in management or even a Ph D. What they learned from us is how to use in context of leisure (where we more vulnerable stand) our own ways of negotiations based on violence and speculation. Further, J. Piazza documented three examples to confirm the acts of terrorism resulted from democracy, in moment when some parties are pushed to clandestinity. In the weak partidocracies, terrorism operates as an instrument of negotiation. Piazza's account not only contradicts almost thousand of studies dedicated to point out that terrorism is a consequence of poverty, but also warns of the problems and inequalities of democracy to balance the interest of all stakeholders (Piazza, 2005).

\section{Conclusion}

Although democracy is two thousand years of age, the division of power which has been the tenet of republic is anew. This surfaced in England after the coup and assassination of Charles I as well as the industrial advance that liberalized all worker bonds. These two events were of paramount importance to forge a new sense of liberty, known in ancient world. The end of WWII consolidated the 
hegemony of Anglo-Empire in hands of US. Democracy as today is conceived resulted from a tergiversation of the old resource of demos, as Castoriadis put it. The Anglo-democracy was based on the doctrine of sovereignty and selfdetermination. The expansion of this ideology was possible thanks to a second concept, the human rights. The gap between citizens and their kings was fulfilled by international business corporations that framed an economic globalization where the capital is replicated. The individual moral agency promoted by Ignatieff is functional to this type of paradigm. As the question has been formulated in the introduction, we are in condition to answer, the doctrine of self determination leads liberalism not to understand the effect of preventive war. Since they estimate that the lesser evil is the best possible course of action, to prevent the downfall of democracy, liberalism precludes that international alliance grant a just application of human rights. Paradoxically, if one state confers authority of intervention of other state this means imperialism. Also human rights as formulated by liberalism are condemned to become in "the dictatorship of human rights".

\section{References}

Albrecth-Meylahn. J. (2013). "Divine Violence as auto-deconstruction: the Christ-event as an Act of Tranversing the neo-liberal fantasy". International Journal of Zizek Studies. Vol 7 (2). 1-19

Appiah A. (2001) "Grounding human rights". ". In Human rights, as politics and idolatry. Michael Ignatieff. New Jersey, Princeton University Press. Pp 101-116

Baudrillard, J. (2006). "Virtuality and Events: the hell of power". Baudrillard Studies. Vol. 3 (2). July. Availabe at http://www.ubishops.ca/BaudrillardStudies/. Bishop's University, Canada. Version translated by Chris Turner.

Castel, R. (1997). La Metamorfosis de la Cuestión social. Una Crónica del salariado. Buenos Aires, Paidos.

Castoriadis, C. (2006). Lo Que Hace a Grecia. De Homero a Heráclito. Buenos Aires, Fondo de Cultura Económica.

Dworking, R. (1996). Freedom's Law: the moral reading of the American Constitution. Massachusetts, Harvard University Press.

Elias, N. (2002). Humana Conditio. Consideraciones en torno a la evolución de la humanidad. Barcelona: Ediciones Península. 
Freeman, M. (2011). Human Rights. An interdisciplinary Approach. Cambridge, Polity Press.

Gutmann, A. (2001) "Introduction". In Human rights, as politics and idolatry. Michael Ignatieff. New Jersey, Princeton University Press. Pp Vii-xxviii.

Hollinger, D. A. (2001). "Debates with the PTA and others". ". In Human rights, as politics and idolatry. Michael Ignatieff. New Jersey, Princeton University Press. Pp 117-126

Ignatieff, M. (2001) Human Rights. As Politics and Idolatry. New Jersey, Princeton University Press (pp. 3-53

Ignatieff, M. (2005). El Mal Menor. Ética Política en una Era de Terror. Bogotá, Taurus.

Korstanje, M. (2013) "Hungtinton \& the Liberal Thought, problems of anglodemocracy to understand politics". Nómadas: revista crítica de Ciencias Sociales y Jurídicas. Número 37 (I). Enero-Junio 2013. Disponible en www.ucm.es/info/nomadas/, www.theoria.eu/nomadas/

Laqueur, T. (2001). "The Moral imagination and Human rights". ". In Human rights, as politics and idolatry. Michael Ignatieff. New Jersey, Princeton University Press. Pp 127-140.

Piazza, J (2005a) "Terrorism and Human Rights: A Cross-National Study." Coauthored with James I. Walsh. Paper prepared for the Annual Meeting of the British International Studies Association, St. Andrews, UK, December 2005.

Piazza, J. (2005b)"Terrorism, Democracy and State Failure in the Middle East: An Empirical Analysis of 19 States." Poster prepared for the Annual Meeting of the American Political Science Association, Washington, D.C., August 2005.

Schopenhauer, A. (2007). Ensayo sobre el Libre Albedrío. Buenos Aires, Gradifico.

Skoll, G. (2007) Meaning of Terrorism,. International Journal for The Semiotics of Law. Vol. 20, pp. 107-127

Sunstein, C. (1993) Partial Constitution. Cambridge, Harvard University Press.

Waltzer, M. (1992) Just and Unjust Wars. A moral argument with historical illustrations. New York, BasicBooks. 